\title{
FINANCIAL MANAGEMENT ELEMENTS SPECIFIC TO INVESTMENTS APPLICABLE IN EDUCATIONAL SYSTEMS
}

\author{
Daniela Alice Luta (Manolescu) ${ }^{1}$ \\ Adrian Ioana $^{2}$ \\ Daniela Tufeanu ${ }^{3}$ \\ Daniela Ionela Juganaru ${ }^{4}$ \\ Bianca Cezarina Ene ${ }^{5}$
}

DOI: https://doi.org/10.31410/LIMEN.2020.337

\begin{abstract}
Our starting point is the definition and classification of investments, both financial and accounting. Thus, in a financial sense, an investment represents the change of an existing and available amount of money, with the hope of obtaining a higher but probable income in the future. In the accounting sense, an investment is the allocation of an amount available for the purchase of an asset, which will determine the future financial flows of income and expenses. Investments can be classified into two categories: domestic investments - consist of the allocation of capital for the purchase of machines, equipment, constructions, licenses, patents, etc. Their purpose can be to reduce costs, increase production, improve quality, increase market share, etc.; foreign investments - consist of capital investments in shares in other companies. They are also called financial investments and aim to increase the value of the company and diversify sources of income. We also analyze in this article the investment decision. The investment decision is the most important financial decision which a manager has to make. An investment usually involves allocating large sums of money in the long run, with a relatively high degree of risk. We also present and analyze both the stages of establishing an investment decision and the methods of evaluating an investment project. The article also presents management elements regarding the investment recovery term; discounted net value method, investment risk assessment.
\end{abstract}

Keywords: Financial management, Investments, Educational systems.

\section{INTRODUCTION}

A $\mathrm{n}$ investment can generally be defined as the process by which something is bought in order to make a profit or interest. In a financial sense, an investment represents the change of an existing and available amount of money, with the hope of obtaining higher incomes in the future (Ioana et al., 2019; Nicolescu et al., 2000). In the accounting sense, an investment represents the allocation of an amount available for the purchase of an asset, which will determine the future financial flows of income and expenses.

Investments can be classified into two categories:

University Politehnica of Bucharest, Spl. Independentei 313, Bucharest, Romania University Politehnica of Bucharest, Spl. Independentei 313, Bucharest, Romania University Politehnica of Bucharest, Spl. Independentei 313, Bucharest, Romania University Politehnica of Bucharest, Spl. Independentei 313, Bucharest, Romania University Politehnica of Bucharest, Spl. Independentei 313, Bucharest, Romania 
Category 1: domestic investments - consist of the allocation of capital for the purchase of machines, equipment, constructions, licenses, patents, etc. Their purpose can be to reduce costs, increase production, improve quality, increase market share, etc.;

Category 2: foreign investments - consist of capital investments in shares or social parts in other companies. They are also called financial investments and aim to increase the value of the company and diversify sources of income.

\section{INVESTMENT DECISION}

The investment decision is the most important financial decision a manager has to make (Ioana, et al., 2015; Ioana, 2009). An investment usually involves allocating large sums of money in the long run with a relatively high degree of risk. Hence the question: Why invest?

Here are some of the reasons behind the decision to invest:

Reason 1: maintaining or increasing the level of profit;

Reason 2: increasing production capacity in order to meet the demand for products or services;

Reason 3: maintaining or increasing the advantage held over the competition;

Reason 4: maintaining or increasing market share;

Reason 5: exploiting the advantages of new technologies;

Reason 6: demand for new products and services.

The stages of establishing an investment decision. In order to decide if you will start investing, we recommend that you go through the following steps (Nicolescu, 1993):

Step 1: Determine the cost of the project.

Make a list of all the costs that will be generated by the investment, from the design to the commissioning of the investment. If you purchase a new machine, be sure to include the training costs of the personnel who will work on that machine. Also, don't forget to include costs for the raw material that will be used at the beginning to adjust the machine (the first products are usually scrapped until the machine is adjusted). If you can afford it, we recommend that you use investment specialists to ensure the success of the project.

Step 2: Determine the financial sources with which the investment will be made.

Will you use your funds or do you need borrowed funds?

Step 3: Forecast estimated cash flows resulting from the investment.

How much money do you estimate you will get over the life of the investment?

Step 4: Determine the total cost of the investment.

Add up the cost of the investment and, if applicable, the cost of the borrowed capital.

Step 5: Compare the total value of estimated cash flows (receipts) with the total cost of the investment.

If the total value of the estimated cash flows is greater than the total cost of the investment, then you can invest. Otherwise, the investment must be abandoned.

\section{METHODS OF EVALUATING AN INVESTMENT PROJECT}

The methods of evaluating an investment project take into account three variables, namely:

- liquidity,

- the time factor, and

- risk. 
There are two main categories of methods for evaluating an investment project:

A. Methods without updating - are quick and simple, but do not take into account the change in the value of money over time.

B. Update methods - are more cumbersome and involve more calculations, but take into account the change in the value of money over time, which is very important especially in an economy with a high annual inflation rate, such as Romania.

The following are two of the most useful methods of evaluating the draft investigation: the investigation recovery period and the net present value method.

\section{The return on investment}

It is the non-updating method of calculating the number of years required to recover the initial investment from the cash flows generated. The term of the investment recovery highlights the measure of the liquidity of an investment and the speed with which the invested money is recovered.

\section{Net Present Value Method (VNA)}

It is the updated method that starts with the idea that the initial investment and the annual cash flows must be converted into values expressed at the same time.

\section{INVESTMENT RISK ASSESSMENT}

The last step you need to take before starting an investment is to assess the risk. All investment experts agree that a low-risk investment has a low rate of return, while a high-risk investment can lead to a high rate of return. The inclusion in a certain degree of risk of the investment is made based on the purpose pursued.

Here are some risk factors to consider when making your checklist:

1. Market forecasts (market exists or not),

2. Technology,

3. Products of the competition,

4. Impact on current activity,

5. The management team,

6. Financial risks,

7. The impact of the legislation,

8. Country risk,

9. Political risk,

10. Environmental risk.

\section{SELECTION OF INVESTMENT PROJECTS}

Selection of investment projects includes the following steps:

Step 1: Formulation of potential investment projects;

Step 2: Application of financial selection criteria; and

Step 3: Investment tracking and control.

Formulation of investment projects. For the selection of proposals, we recommend you to adopt a procedure for analyzing potential decentralized investment projects, with two levels:

- The lower level (section, division, branch), regarding the replacement and modernization investments, as well as the investments for the development of the activity; 
- The upper level, of the company's management, regarding the strategic, human, and social investments.

Feasibility calculation. Each investment proposal must be accompanied by a feasibility calculation, highlighting mainly the capacity of the project in question to bring profit and, consequently, to allow the recovery of the initial investment.

\section{TYPES OF INVESTMENTS}

We recommend that, in the procedure of choosing an investment project, you take into account the characteristics of that project. These will place it in one of the following categories.

Category 1: Replacement and modernization investments - are investments intended to replace physically and morally used tangible assets. These investments have the same use-value as the replaced ones.

Category 2: Development or expansion investments - are those investments that lead to the growth and development of the company. These investments can be made in the form of:

- internal growth, which involves the development of the company (its production capacity) through actual investments;

- external growth, which involves the development of the company through the acquisition of another company.

Category 3: Strategic investments - are those investments related to the strategic option of the company. For example, a research project related to the exploitation or creation of a new product, the decision to merge with another company, etc.

Category 4: Investments in human capital - are the expenses regarding selection and hiring of staff, specialists, management team; and permanent formation of human capital.

These investments are of great importance because they can avoid large expenses, generated by hiring inadequate staff, dismissal, and hiring new staff.

\section{CONCLUSION}

Educational systems, at any level, are in dire need of investment. After investing in human resources, which is the most important, material investments also have a very important role. Efficient material investments in educational systems ensure the necessary (and not sufficient) conditions for increasing the quality of the respective educational process. Hence the need for scientific knowledge about investments.

The starting point of this knowledge must be the understanding of the five types of definitions of an investment (which is also a classification of investments): investment in the general sense, investment in a financial sense, investment in an accounting sense, internal investment, and external investment.

The investment decision is also very important. This decision must be made on a scientific basis, including a good feasibility study. Among the arguments underlying the decision to invest, we mention: increasing the educational capacity to be able to satisfy the demand for services, maintaining or increasing the advantage held over the competition, maintaining or increasing market share, and exploiting the advantages of new technologies. 
Knowing the stages of establishing an investment decision and its scientific application are also very important. These steps are as follows: determine the cost of the project; determining the financial sources with which the investment will be made; forecasting cash flows estimated as a result of the investment; determine the total cost of the investment; comparing the total value of estimated cash flows (receipts) with the total cost of the investment.

\section{REFERENCES}

Ioana, A. (2009). Managementul activităţii financiar-contabile şi analize economice. Teorie şi Aplicaţii, Bucureşti, Editura Politehnica Press.

Ioana, A., Marcu D. \& Barbu, C.A. (2015). Analize economico-financiare-teorie si aplicatii. M Costoiu, A. Semenescu, (Coordonator), Editura Matrix Rom, Bucureşti.

Ioana, A., Tufeanu, D. \& Labes, D.C. (2019). Management financiar. Teorie si aplicatii. Ed. Printech.

Nicolescu, O. (1993). Ghidul managerului eficient, Bucureşti, Ed. Tehnică.

Nicolescu, O. et al., (2000). Sisteme, Metode şi Tehnici manageriale ale organizaţiei, Bucureşti, Ed. Economică. 